\title{
Management of Citrus Leaf and Fruit Spot (Pseudcercospora angolensis) Disease Using Fungicides
}

\author{
Mandefro Aslake ${ }^{1}$, Assefa Sintayehu ${ }^{1, ~ *, ~ C h e m e d a ~ F i n i n s a ~}{ }^{2}$, Teferi Alem ${ }^{1}$ \\ ${ }^{1}$ College of Agriculture and Environmental Sciences, University of Gondar, Gondar, Ethiopia \\ ${ }^{2}$ School of Plant Sciences, University of Haramaya, Haramaya, Ethiopia
}

Email address:

kassaassefa@gmail.com (A. Sintayehu)

*Corresponding author

\section{To cite this article:}

Mandefro Aslake, Assefa Sintayehu, Chemeda Fininsa, Teferi Alem. Management of Citrus Leaf and Fruit Spot (Pseudcercospora angolensis) Disease Using Fungicides. Agriculture, Forestry and Fisheries. Vol. 10, No. 5, 2021, pp. 170-175.

doi: $10.11648 /$ j.aff.20211005.11

Received: September 17, 2021; Accepted: October 4, 2021; Published: October 12, 2021

\begin{abstract}
In Tropical Africa, particularly Sub-Saharan Africa production of citrus is seriously hampered by citrus leaf and fruit spot (Pseudocercospora angolensis) disease. The yield reduction due to this disease can reach $50 \%-100 \%$ when climatic conditions are favorable to the disease development and effective control measures are not implemented timely. Hence, this study was anticipated to evaluate the effect of fungicides for the management of citrus leaf and fruit spot disease. As the result of this, the efficacy of different fungicides namely; Carbonchlor $50 \%$ SC only, Benline $50 \%$ WP only, Bellis $38 \%$ WG only, Carbonchlor 50\% SC combined with Bellis 38\% WG, Benline 50\% WP combined with Carbonchlor $50 \%$ SC and Benline 50\% WP combined with Matco 72\% WP against Pseudocercospra angolensis were tested under field conditions. The present field experiment result showed that, there was no infected fruit observed in all treated trees as compared to the control plot that revealed $(33.12 \%)$ fruit infection. Whereas, in leaves minimum infection rate $(1.16 \%)$ was recorded from trees treated with Bellis 38\% WG followed by Carbonchlor 50\% SC (1.48\%), Carbonchlor 50\% SC combined with Bellis 38\% WG $(1.89 \%)$, Benline 50\% WP combined with Carbonchlor 50\% SC (4.00\%), Benline 50\% WP (4.54\%) and Matco 72\% WP combined with Benline 50\%WP (6.24\%). However, maximum infection rate $(17.57 \%)$ was recorded from leaves of unsprayed check. Therefore, from the results of the present investigation, application of Carbonchlor $50 \% \mathrm{SC}$ was the first choice to be used followed by Carbonchlor 50\% SC + Benline 50\% WP, Bellis 38\% WG + Carbonchlor 50\% SC, Bellis 38\% WG only, Benline $50 \%$ WP only and Matco $72 \%$ WP + Benline $50 \%$ WP for the management of citrus leaf and fruit spot disease.
\end{abstract}

Keywords: Leaf and Fruit Spot, Citrus, Fungicides, Relative Yield Loss, Severity

\section{Introduction}

Citrus is the worlds' second largest fruit by production volume next to banana and it has got multiple advantages including food source, raw material for agro-industries, income generation and source of employment [17]. Although the exact time of citrus introduction to Ethiopia is not known, its production started seven decades ago by expatriates and some government officials [11, 19]. Since then, its economic importance is on the rise. Oranges, mandarins, limes, lemons and grape fruits are the major commercial citrus species that are cultivated by both small holder and commercial farmers [19, 12].

The average acreage and annual production of citrus in
Ethiopia are estimated at 7,040 hectares and 72,459 tons, respectively [6, 7]. Large portion of citrus fruits produced are consumed locally as fresh fruit, juice and marmalade [19]. Some citrus fruits such as sweet orange and lime are exported to Djibouti, Europe and the Middle East [9].

In Ethiopia, leaf and fruit spot (Pseudocercospora angolensis) disease was first reported in 1988 from the Southern part of the country [20]. Later, it spreads to South, Southwest, and Northwest parts of the country and cause heavy crop damage, often total crop loss [12].

The disease attacks leaves, fruits and twigs of all citrus species at various levels of severity [13]. Nowadays, it becomes so destructive in these parts of the country that some of the farmers are obliged to up root sweet orange trees and 
replace them with other crops [10]. As the result of this, it is exceedingly necessary to reverse the damage caused by the disease. Therefore, the objective of this study was to evaluate the effect of fungicides for the management of citrus leaf and fruit spot (Pseudcercospora angolensis) disease.

\section{Materials and Methods}

\subsection{Description of the Study Area}

The experiment was conducted at Bikolo Fruit Crops Multiplication Nursery in Mecha district, North Western Ethiopia, during 2020/2021. Selection of the study site was made based on; its liability to the disease, the availability of enough number of sweet orange trees for the test and accessibility. The site was located $11^{\circ} 33^{\prime} 45^{\prime \prime}$ North latitude to $37^{\circ} 16^{\prime} 14^{\prime \prime}$ East longitude and at an altitude of 1850 m.a.s.1. And its daily average temperature and annual rain fall are $24^{\circ} \mathrm{C}$ and $2000 \mathrm{~mm}$, respectively.

\subsection{Treatments, Field Management and Experimental Design}

The trial contained seven treatments: Carbonchlor 50\% SC, Benline 50\% WP, Bellis 38\% WG, Carbonchlor 50\% SC combined with Bellis 38\% WG, Benline 50\% WP combined with Carbonchlor 50\% SC, Benline 50\% WP combined with Matco 72\% WP and control (water). The fungicides were applied based on the manufacturers' recommendation rate i.e., $20 \mathrm{ml}$ and $20 \mathrm{mg}$ per 10 liters of water for liquid and solid formulations, respectively. In order to spray fungicides thoroughly, Knapsack sprayer was used for applying. And the timing of application was started at the onset of the disease and had been continued at fourteen days of interval until one week left for harvesting. And during application, to avoid drift problem the plots under application were protected with plastic sheet supported by four wooden poles.

The experiment was set in Randomized Complete Block Design (RCBD) with three replications. Hence, a total of 21 long-standing that were 22 years old sweet orange trees were chosen for the test as experimental unit.

\subsection{Disease Assessment}

Disease incidence was estimated both on leaves and fruits of the tree. On leaves, it was estimated by counting visibly infected and total number of leaves on eight randomly selected terminal shoots from the upper and lower halves of the canopy in four directions (North, South, East and West) of each selected tree, and expressed as a percentage [3]. It was computed using the following formula, suggested by [14] as:

$$
\text { Disease incidence on leaves }(\%)=\frac{\text { no of leaves infected per tree }}{\text { Total no of assessed leaves per tree }} \times 100
$$

And on fruits, disease incidence was assessed on 5 to 40 randomly selected intact fruits in four directions of each tree based on the presence or absence of visible disease

symptoms on each fruit, depending on availability [3]. It was calculated by using [14] formula:

$$
\text { Disease incidence on fruits }(\%)=\frac{\text { no of infected fruits per tree }}{\text { Total no of assessed fruits per tree }} \times 100
$$

Disease severity was assessed on the same leaf and fruit samples taken for disease incidence scoring. On leaves, it was estimated based on a zero-to-four scoring scale, where 0 $=$ no symptoms, $1=1$ to $25 \%, 2=26$ to $50 \%, 3=51$ to $75 \%$ and $4=$ above $75 \%$ of leaf area infected $[2,8]$.

And on fruits, severity was recorded using the following zero to four scoring scale, where $0=$ healthy, $1=$ less than $5 \%, 2=5$ to $20 \%, 3=21-50 \%$ and $4=$ above $50 \%$ of fruit surface affected [18].

For analysis, severity grades were converted into percentage severity index (PSI) and calculated using the formula suggested by [5]:

$$
\text { PSI }=\frac{\text { Sum of all numerical ratings }}{\text { Total no.of observations } \times \text { Maximum disease score }} \times 100
$$

From the severity data, AUDPC for each treatment was calculated as described by [4] as follow:

$$
\mathrm{AUDPC}=\sum_{i=1}^{n}[(\mathrm{xi}+\mathrm{xi}-1) / 2][\mathrm{ti}-\mathrm{ti}-1]
$$

Where, $\mathrm{x}_{\mathrm{i}}=$ Present disease severity

$\mathrm{xi}-1=$ Previous disease severity

$\mathrm{t}_{\mathrm{i}-\mathrm{t}_{\mathrm{i}}-1}=$ Time difference between two consecutive disease severities.; and $\mathrm{n}$ - is the total number of days disease severity was assessed.

\subsection{Yield Loss Assessment}

Fruit Yield (kg/tree) from treated and untreated trees was taken. And Relative Yield Loss (RYL) was calculated using the following [15] formula:

$$
\text { RYL }(\%)=\frac{(Y P-Y U P)}{Y P} \times 100
$$

Where, RYL = Relative yield loss (reduction of the yield), $\mathrm{YP}=$ Mean of yield obtained from maximum protected plots, YUP $=$ Mean of yield obtained from unprotected plots or sprayed plots with varying level of disease.

\subsection{Fungicide Efficacy}

The efficacy of fungicides was calculated using [1] formula:

$$
\mathrm{EF}(\%)=\frac{\mathrm{X}-\mathrm{Y}}{\mathrm{X}} \times 100
$$

Where, 
$\mathrm{X}$ - Disease severity in control plots

$\mathrm{Y}$ - Disease severity in treated plots.

\subsection{Data Analysis}

All recorded parameters were analyzed by analysis of variance and tested for comparison of treatments at 0.01/0.05 level of probability using least significant difference (LSD). SAS separate analysis of variance, version 9.2 [16] was the statistical package used for analysis.

\section{Results and Discussion}

\subsection{Effect of Fungicides on the Incidence of the Disease}

In leaves, significant differences at $(\mathrm{P}<0.05)$ were recorded among different treatments (Table 1). Minimum percentage $(1.16 \%)$ of infected leaves was recorded in Bellis $38 \% \mathrm{WG}$ treated trees. While, the maximum $17.57 \%$ of infected leaves was recorded in the unprotected check.

Table 1. The effect of fungicides on citrus leaf and fruit spot disease incidence of leaves.

\begin{tabular}{|c|c|c|c|c|c|c|c|c|c|}
\hline \multirow{3}{*}{ Treatments } & \multicolumn{9}{|c|}{ Disease incidence } \\
\hline & \multicolumn{9}{|c|}{ Days after the first spray } \\
\hline & 14 & 28 & 42 & 56 & 70 & 84 & 98 & 112 & 126 \\
\hline 1. Control & 1.66 & 2.42 & 3.33 & 8.77 & 13.78 & 25.17 & 35.78 & 49.66 & $17.57^{\mathrm{a}}$ \\
\hline 2. Matco $72 \% \mathrm{Wp}+$ Benline $50 \% \mathrm{WP}$ & 0.0 & 0.0 & 2.10 & 3.24 & 5.89 & 10.33 & 13.24 & 15.16 & $6.24^{\mathrm{b}}$ \\
\hline 3. Benline $50 \%$ WP only & 0.0 & 0.0 & 1.56 & 2.18 & 4.50 & 6.19 & 10.03 & 11.89 & $4.54^{\mathrm{bc}}$ \\
\hline 4. Carbonchlor $50 \% \mathrm{SC}+$ Benline $50 \% \mathrm{WP}$ & 0.0 & 0.0 & 0.0 & 1.44 & 3.98 & 5.68 & 9.85 & 11.10 & $4.00^{\mathrm{bc}}$ \\
\hline 5. Bellis 38\% WG + Carbonchlor $50 \% \mathrm{SC}$ & 0.0 & 0.0 & 0.0 & 0.0 & 1.52 & 3.22 & 4.89 & 5.48 & $1.89^{\mathrm{c}}$ \\
\hline 7. Bellis $38 \%$ WG & 0.0 & 0.0 & 0.0 & 0.0 & 0.0 & 1.65 & 3.25 & 4.42 & $1.16^{\mathrm{c}}$ \\
\hline
\end{tabular}

The day 126 from the first fungicides spray, is the mean of the three replications; means followed by the same letter are not significantly different by LSD (P $<0.05)$.

In fruits, the highest infection rate (33.12\%) was recorded in the unsprayed check. Whereas, there was no disease infection symptom observed in all fruits of trees treated with different fungicides at all (Table 2).

Table 2. Recorded disease incidence of fruits.

\begin{tabular}{|c|c|c|c|c|c|c|c|c|c|c|c|c|}
\hline \multirow{2}{*}{ Treatments } & \multicolumn{11}{|c|}{ Days after the first spray and disease incidence (\%) } & \multirow{2}{*}{$\begin{array}{l}\text { Mean } \\
170 *\end{array}$} \\
\hline & 14 & 28 & 42 & 56 & 70 & 84 & 98 & 112 & 126 & 140 & 156 & \\
\hline Carbonchlor $50 \% \mathrm{SC}$ & & 0 & 0 & 0 & 0 & 0 & 0 & 0 & 0 & 0 & 0 & 0 \\
\hline Carbonchlor $50 \% \mathrm{SC}+$ Benline $50 \% \mathrm{WP}$ & 0 & 0 & 0 & 0 & 0 & 0 & 0 & 0 & 0 & 0 & 0 & 0 \\
\hline Bellis $38 \% \mathrm{WG}+$ Carbonchlor $50 \% \mathrm{SC}$ & 0 & 0 & 0 & 0 & 0 & 0 & 0 & 0 & 0 & 0 & 0 & 0 \\
\hline Bellis $38 \%$ WG only & 0 & 0 & 0 & 0 & 0 & 0 & 0 & 0 & 0 & 0 & 0 & 0 \\
\hline Benline $50 \% \mathrm{WP}$ only & 0 & 0 & 0 & 0 & 0 & 0 & 0 & 0 & 0 & 0 & 0 & 0 \\
\hline Matco $72 \% \mathrm{WP}+$ Benline $50 \% \mathrm{WP}$ & 0 & 0 & 0 & 0 & 0 & 0 & 0 & 0 & 0 & 0 & 0 & 0 \\
\hline
\end{tabular}

The day $* 170$ after the first fungicides spray is the mean of the three replications.

\subsection{Effect of Fungicides on the Severity of the Disease}

The statistical analysis showed that significant differences at $(\mathrm{P}<0.05)$ were observed among treatments (Table 3). Minimum percentage of disease severity (1.73\%) of leaves was recorded in Bellis $38 \% \mathrm{WG}$ treated trees. However, maximum percentage $(18.15 \%)$ of disease severity of leaves was recorded in the control plots.

Table 3. The effect of fungicides on citrus leaf and fruit spot disease severity (PSI) of leaves.

\begin{tabular}{|c|c|c|c|c|c|c|c|c|c|}
\hline \multirow{3}{*}{ Treatments } & \multicolumn{9}{|c|}{ Disease severity (PSI) } \\
\hline & \multicolumn{9}{|c|}{ Days after the first spray } \\
\hline & 14 & 28 & 42 & 56 & 70 & 84 & 98 & 112 & 126 \\
\hline 1. Control & 1.69 & 2.4 & 4.33 & 8.39 & 18.05 & 31.85 & 37.84 & 40.67 & $18.15^{\mathrm{a}}$ \\
\hline 2. Matco $72 \% \mathrm{Wp}+$ Benline $50 \% \mathrm{WP}$ & 0.0 & 0.0 & 2.06 & 3.18 & 8.49 & 16.66 & 20.17 & 22.78 & $9.17^{\mathrm{b}}$ \\
\hline 3. Benline $50 \%$ WP only & 0.0 & 0.0 & 1.59 & 3.17 & 6.03 & 10.56 & 13.67 & 14.88 & $6.24^{\mathrm{bc}}$ \\
\hline 4. Carbonchlor $50 \% \mathrm{SC}+$ Benline $50 \% \mathrm{WP}$ & 0.0 & 0.0 & 0.0 & 1.48 & 3.96 & 9.65 & 14.98 & 16.51 & $5.83^{\mathrm{bc}}$ \\
\hline 5. Bellis 38\% WG + Carbonchlor 50\% WP & 0.0 & 0.0 & 0.0 & 0.0 & 2.06 & 4.9 & 8.62 & 10.45 & $3.27^{c}$ \\
\hline 7. Bellis $38 \%$ WG & 0.0 & 0.0 & 0.0 & 0.0 & 0.0 & 1.66 & 5.78 & 6.46 & $1.73^{\mathrm{c}}$ \\
\hline
\end{tabular}

The day 126 after the first fungicides spray, is the mean of the three replications; means followed by the same letter are not significantly different by LSD (P $<0.05)$.

In fruits, the highest disease severity $(35.66 \%)$ was recorded in unsprayed trees. Whereas, it was zero in all fruits of trees treated with different fungicides (Table 4). 
Table 4. Recorded disease severity of fruits.

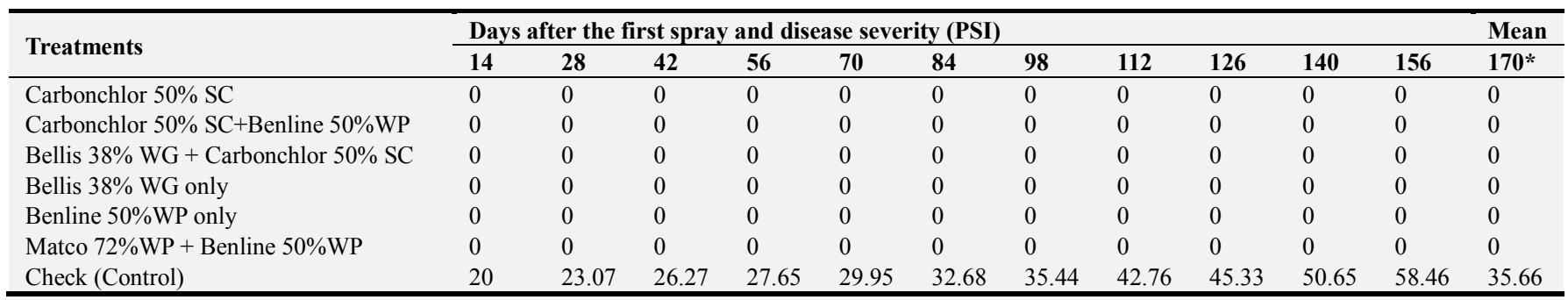

*170 days after the first fungicides spray is the mean of the three replications.

\subsection{The Effect of Fungicides on Area Under the Disease Progress Curve (AUDPC)}

Low rate of AUDPC (Area Under the Disease Progress Curve) was computed by Bellis $38 \%$ WG that was (149.38) followed by Carbonchlor 50\% SC (220.92), Bellis 38\% WG combined with Carbonchlor 50\% SC (292.25), Benline 50\%
WP combined with Carbonchlor 50\% SC (536.55), Benline $50 \%$ WP (594.44) and Matco 72\%WP combined with Benline 50\% WP (867.30). Whereas, it was (1736.56) by the unsprayed check (Figure 1). From this, it is possible to discuss that, all applied fungicides were effective in controlling the disease as compared to the unsprayed check that scored the highest rate.

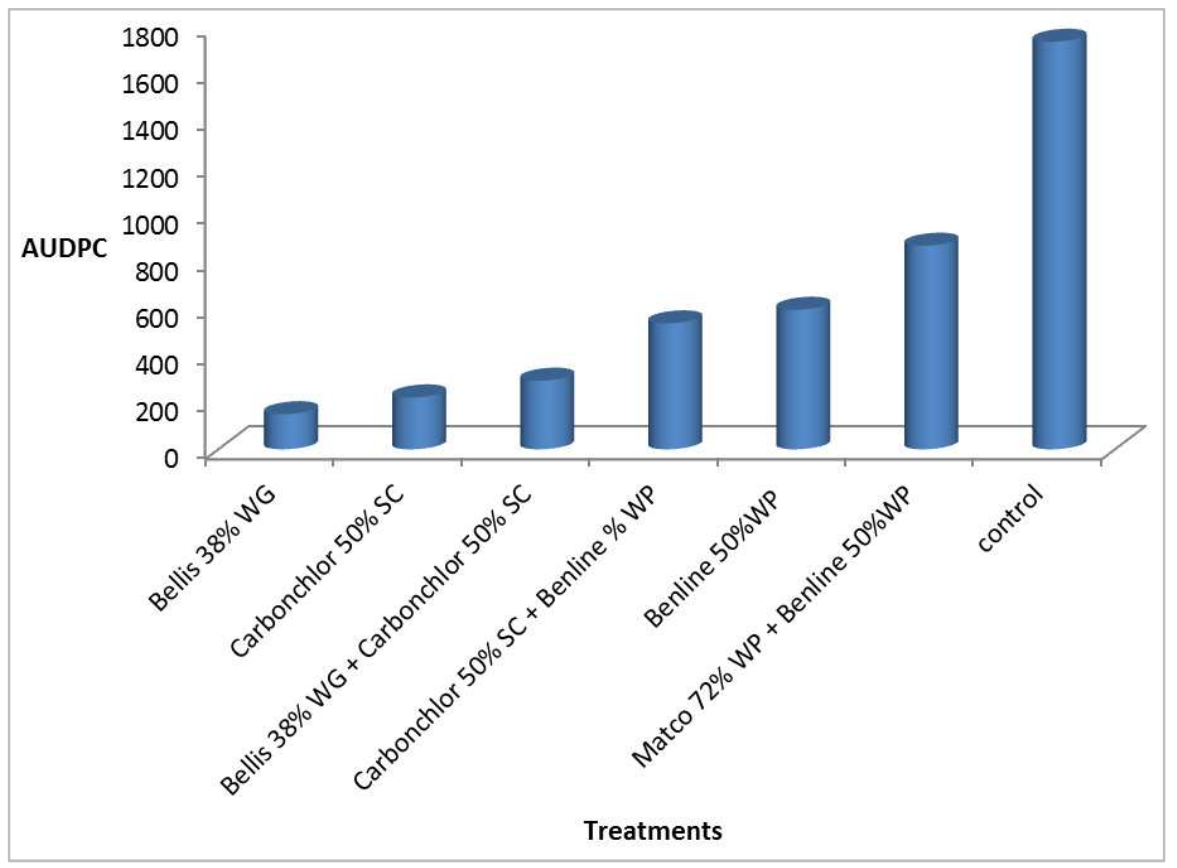

Figure 1. Area Under the Disease Progress curve of each treatment against citrus leaf and fruit spot disease of leaves.

\subsection{Effect of Fungicides on Reducing Yield Loss}

Based on the effect of fungicides on reducing yield loss, effective protection and the highest mean yield $(104 \mathrm{~kg} /$ tree $)$ were obtained from Carbonchlor $50 \% \mathrm{SC}$ treated plots followed by Carbonchlor 50\% SC + Benline 50\%SC (87 $\mathrm{kg} /$ tree), Bellis 38\% WG + Carbonchlor 50\% SC $(65$ $\mathrm{kg} /$ tree), Bellis $38 \% \mathrm{WG}$ only (56 kg/tree), Benline $50 \% \mathrm{WP}$ only (48 kg/tree) and Matco 72\% WP + Benline 50\% WP (41 $\mathrm{kg} /$ tree) treated plots (Table 5). While, the lowest mean yield $(8 \mathrm{~kg} /$ tree $)$ was gained from unprotected check plots.

Table 5. Calculated relative yield loss of the treatments.

\begin{tabular}{|c|c|c|c|}
\hline No & Treatments & Average fruit yield in $\mathrm{Kg} /$ tree & Relative yield loss (\%) \\
\hline 1 & Control & 8 & 92.30 \\
\hline 2 & Matco $72 \% \mathrm{WP}+$ Benline $50 \% \mathrm{WP}$ & 41 & 60.57 \\
\hline 3 & Benline $50 \%$ WP only & 48 & 53.84 \\
\hline 4 & Bellis $38 \%$ WG only & 56 & 46.15 \\
\hline 5 & Bellis $38 \% \mathrm{WG}+$ Carbonchlor $50 \% \mathrm{SC}$ & 65 & 37.50 \\
\hline 6 & Carbonchlor $50 \% \mathrm{SC}+$ Benline $50 \% \mathrm{SC}$ & 87 & 16.35 \\
\hline 7 & Carbonchlor $50 \%$ SC only & 104 & 0.0 \\
\hline
\end{tabular}




\subsection{Fungicide Efficacy (FE)}

Based on the efficacy level of the fungicides, the highest level of efficacy $(90.46 \%)$ was produced by Bellis $38 \% \mathrm{WG}$ treated trees followed by Carbonchlor 50\% SC (86.50\%),
Bellis $38 \% \mathrm{WG}+$ Carbonchlor $50 \% \mathrm{SC} \quad(82.00 \%)$, Carbonchlor 50\%SC + Benline 50\%WP (67.89\%), Benline $50 \% \mathrm{WP}(65.62 \%)$ and Matco $72 \% \mathrm{WP}+$ Benline 50\%WP (49.48\%) (Table 6).

Table 6. The level of efficacy of fungicides against citrus leaf and fruit spot disease.

\begin{tabular}{llll}
\hline No & Treatments & Disease severity (PSI) & The level of efficacy \\
\hline 1 & Bellis 38\%WG only & 1.73 & 90.46 \\
2 & Carbonchlor 50\%SC only & 2.45 & 86.50 \\
3 & Bellis 38\%WG + Carbonchlor 50\%SC & 3.27 & 82.00 \\
4 & Carbonchlor 50\%SC + Benline 50\%WP & 5.83 & 67.89 \\
5 & Benline 50\%WP only & 6.24 & 65.62 \\
6 & Matco 72\%WP + Benline 50\%WP & 9.17 & 49.48 \\
7 & Control & 18.15 & - \\
\hline
\end{tabular}

\section{Conclusion and Recommendation}

The present study results revealed that in leaves, maximum disease incidence and severity i.e., (17.57\%) and (18.15\%), respectively and the highest AUDPC (1736.56) were recorded in unsprayed check. Whereas, the lowest disease incidence, severity and AUDPC i.e., (1.16\%), (1.73\%) and (149.38), respectively were observed from Bellis $38 \%$ WG treated plots. In fruits, it was only in the unsprayed check that $(33.12 \%)$ and $(35.66 \%)$ disease incidence and severity were recorded, respectively. And also, the highest fruit yield reduction i.e., $(92.30 \%)$ was observed in unprotected check plots. However, there was no infected fruit observed in all plots treated with different fungicides. As a result, Carbonchlor $50 \%$ SC was the best effective fungicide in controlling the disease and providing the highest yield (104 $\mathrm{kg} /$ tree) followed by Carbonchlor $50 \% \mathrm{SC}+$ Benline $50 \% \mathrm{WP}$ (87 kg/tree), Bellis 38\% WG + Carbonchlor $50 \%$ SC $(65$ $\mathrm{kg} /$ tree $)$, Bellis $38 \% \mathrm{WG}$ only ( $56 \mathrm{~kg} /$ tree $)$, Benline $50 \% \mathrm{WP}$ only (48 kg/tree) and Matco 72\% WP + Benline 50\% WP (41 $\mathrm{kg} /$ tree).

Therefore, from the results of the present investigation, application of Carbonchlor $50 \% \mathrm{SC}$ was the first choice to be used followed by Carbonchlor 50\% SC + Benline 50\% WP, Bellis 38\% WG + Carbonchlor 50\% SC, Bellis 38\% WG only, Benline 50\% WP only and Matco $72 \%$ WP + Benline $50 \%$ WP for the management of citrus leaf and fruit spot disease.

It is further recommended that, to provide sustainable citrus fruit production and productivity in the country, additional management strategies through host resistance, fungicides integrated with cultural and agronomic practices against citrus leaf and fruit spot disease should be premeditated.

\section{References}

[1] Abbott, W. S. (1925). A method of computing the effectiveness of an insecticide. J. Econ. Entomol. 18: 26.5267.
[2] Amadi, J. E. (2008). Studies of the etiology of leaf spot of disease of rough lemon (Citrus jambhiri - B. Jamir; H. Jhambhiri). Bio-Research, 6: 343-345.

[3] Asmare, D., Derbew, B., Belayneh, A; \& Mohammed, Y. (2014). Citrus Production, Constraints and Management Practices in Ethiopia: The Case of Pseudocercospora Leaf and Fruit Spot Disease. Sci. Technol. Arts Res. J., 3 (2): 04-18.

[4] Campbell, C. L; \& Madden, L. V. (1990). Introduction to Plant Disease Epidemiology. John Wileey and Sons New York, USA.

[5] Chaube, H. S; \& Singh, U.S. (1991). Plant disease management: Principles and Practices. CRC Press, Boca Raton, Florida.

[6] CSA (Central Statistical Agency). (2015a). Large and medium scale commercial farms Sample survey 2014/25, Vol. 8. Statistical Bulletin. CSA, Addis Ababa, Ethiopia.

[7] CSA (Central Statistical Agency). (2015b). Agricultural sample survey 2014/2015: Report on area and production of major crops for private peasant holding, Vol. 1. Statistical Bulletin 578. CSA, Addis Ababa, Ethiopia.

[8] Ezeibekwe, I. O. (2011). Study of citrus disease prevalence on four citrus varieties at the National Institute of Horticultural Research (NIHORT) Mbato, Okigwe, Imo State, Nigeria. African Journal of Plant Science, 5: 360-364.

[9] Joosten, F; Boselie, D; Wolde, B; \& Dessalegn, L. (2011). Exporting fruit and vegetables from Ethiopia: Assessment of development potentials and investment options in the export- oriented fruit and vegetable sector. Ethiopia Netherlands Horticulture Partnership Program, Addis Ababa, Ethiopia.

[10] Kuate, J; Jazet Dongmo, P. M., Ducelier, D., Damesse, F., Menut, C; \& Bessiere, J. M. (2003). Effect of citrus leaf spot disease (Phaeoramularia angolensis) on the content and chemical composition of essential oils from orange peel. Fruits 58: 143-149.

[11] Mohammed Yesuf. (2002). Phaeoramularia leaf and fruit spot of citrus: a major threat to citrus production in tropical Africa, present status and future perspectives. pp. 18-25.

[12] Mohammed Yesuf. (2007). Distribution and management of Phaeoramularia leaf and fruit spot disease of citrus in Ethiopia. Fruits, 62: 99-106. 
[13] Mohammed Yesuf. (2013). Pseudocercospora leaf and fruit spot disease of citrus: achievements and challenges in the citrus industry: a review. Agricultural Sciences, 4: 324-328.

[14] Nwanosike, M. R. O; Mabagala, R. B; \& Kusolwa P. M. (2015). Disease intensity and distribution of Exserohilum turcicum Incitant of Northern Leaf Blight of Maize in Tanzania. International Journal of Pure and Applied Biosciences 3 (5): 1-13.

[15] Robert, K., \& Janes, N. (1991). Seed Pathology (Revised ed.). Edition Vol. II. The Mac Millan Press Ltd.

[16] SAS (Statistical Analysis System). (2011). Version 9.2 Computer Software. Retrieved from WWW. Statsoft.com
[17] Seif, A. A. (1994). Studies on Phaeoramularia fruit and leaf spot disease of citrus in Kenya. PhD Thesis, University of Reading.

[18] Seif, A. A; \& Hillocks, R. J. (1996). Epidemiology of fruit and leaf spot of citrus caused by Phaeoramularia angolensis in Kenya: An Overview. Proceedings of the International Society of Citriculture 1: 338-339.

[19] Seifu Gebre-Mariam. (2003). Status of commercial fruit production in Ethiopia. Ethiopian Agricultural Research Organization, Addis Ababa, Ethiopia. 91p.

[20] Yimenu, J. (1993). Preliminary survey report on leaf spot disease of citrus in Sidamo. Coffee Development Authority, Addis Ababa, Ethiopia. 